\title{
三点曲げを受ける異種材積層はりのはく離の局所座屈*
}

\author{
深川和 良*1, 小田美紀男*2 \\ 有 冨 正 男*2, 戸谷眞 之*2

\section{Local Delamination Buckling of a Laminated Beam Due to Three-Point Bending}

\author{
Kazuyoshi FUKAGAWA*3, Mikio ODA, \\ Masao ARITOMI and Masayuki TOYA \\ ${ }^{* 3}$ Production Technology Department, Kumamoto Industrial Reseach Institute, \\ 3-11-38 Higashimachi, Kumamoto-shi. Kumamoto, 862-0901 Japan
}

\begin{abstract}
Asymmetric three-point bending of a layered beam containing an interior interface crack is analyzed on the basis of classical beam theory. The point of load application is assumed to lie on the delaminated part, so that a part of the crack faces is contacting one another, while the remaining part of the crack faces is open. Axial compressive and tensile forces are induced by bending in the parts of the beam above and below the delamination and they are determined by modeling the cracked part as two lapped beams hinged at both ends. When the magnitude of the applied load is small, the beam deflects retaining mutual contact of whole crack faces, but as the applied load reaches a critical value, local delamination buckling occurs. The relation between the magnitude of the applied load and the deflection at the point of load application is found to be nearly bilinear. The validity of this prediction is confirmed by experiments. It is also shown that once the delamination buckling occurs, energy release rate generally becomes larger as compared with the case of perfect contact of delaminated surfaces.
\end{abstract}

Key Words: Fracture Mechanics, Delamination, Laminated Construction, Three-point Bending, Buckling, Energy Release Rate

\section{1. 緒 言}

積層はりや積層板においては，製造工程中の不具合 や積層材表面に垂直に加えられた低速度衝撃により, 接着面（界面）のはく離が容易に生じることが知られ ている. 破壊力学の観点からは，皘層材を使用するに あたっては，あらかじめはく離の存在を想定し，それ がいかなる条件のもとで進展するかを把握しておくこ とが不可欠である.

Maikuma ら ${ }^{(1)}$ は対称三点曲げを受ける二枚の等方性 の同質材で作られた積層はり中央の界面はく離を研究 した. Suemasu と Majima ${ }^{(2)(3)}$ は, 中心に集中力を受け る多層円板中の多重円形界面はく離の進展を扱ってい る. Hutchinson と $\mathrm{Lu}^{(4)}$ は直交異方性はり中の界面はく 離が温度こう配下にあるときのエネルギ一解放率を導

* 原稿受付 2006 年 4 月 18 日.

*1 正員, 熊本県工業技術センター(画862-0901 熊本市東町 311-38).

*2 正員, 鹿児島大学工学部(牢890-0065 鹿児島市郡元 1-2140).
いた. Toya ら ${ }^{(5)}$ は, 界面はく離を有する異種材からな る積層はりが非対称三点曲げを受ける場合の解析を行 った. はり理論に基づき, 負荷点のたわみを外力とは く離長さの関数として得，これより，はく離端におけ るエネルギー解放率とそのモード I，モード II 成分を 導いた.

Toya ら ${ }^{(5)}$ の解析モデルでは，はく離面が全面接触し ていることが仮定されていた. しかしながら，この仮 定は小さな負荷に対しては正しいが，大きな曲げのも とでは, 曲げに起因する圧縮力によりはく離部分で座 屈が生じる. 荒井ら ${ }^{(6)}$ は，四点曲げのもとで基材に施 された皮膜が座屈を起こし，界面に沿ってはく離が進 展することを実験的に明らかにした．座屈が起こる場 合は, はく離面上下のはりのたわみは異なっているも のとして，解析をする必要がある. 戸谷ら ${ }^{(7)}$ は三点， および四点曲げを受ける積層はり中のはく離部分が座 屈を起こす場合についてたわみの解析と実験を行った. ただし，この取り扱いでは負荷点は接着部分上にある ことが仮定されており，解析結果の適用範囲は限定さ 
れている：現実には，例えば低速度衝撃によるはく離 進展問題においては，はく離は負荷点直下の界面で生 じる (図 1参照)。したがって一般には, はく離の上下 面の一部は互いに接触し, 他の部分で座屈を起こすと 考えられる.

本論文では，三点曲げによるはく離部の局所座屈問 題を一般的に扱うために，この接触とはく離の混合問 題について解析し，ついで実験により理論の精度を確 認する. また，座屈時のエネルギー解放率を計算し， 接触解のそれと比較し，座屈によりはく離倠展がどれ ほど容易になるかを定量的に明らかにする。

\section{2. 局所座届の解析}

\section{$2 \cdot 1$ 集中力がはく離部分上に作用する場合の局所}

\section{座屈 モデルを図 1 に示す. 上下のはりは等方弾性} 体であると仮定するが，異方性の主軸がはりの軸に一 致する場合は以下の理論は直交異方性のはりに対して も適用できる.二本の異種材からなる矩形断面のはり を接着して作られたはく離（界面クラック）を含む積 層はりを考え，このはりが非対称三点曲げを受ける場 合について解析寸る. はりの長さ (=支点間距離) を $L$, はりの幅,厚さ,ヤング率及び断面二次モーメントは, それぞれ $b_{i}, h_{i}, E_{i}, I_{i}(i=1,2)$ とする. 添字の 1 , 2 はそれぞれ上層, 下層を意味する. 今, 長さcのは く離が含まれていると仮定し，左右のはく離端のはり の端からの距離はそれぞれ $a_{L}$ および $a_{R}$ であるとす る.またはく離左端から負荷点までの距離 $(\mathrm{BC}) を c_{L}$ ， 右端から負荷点までのそれ（CD）を $c_{R}$ とする $\left(c=c_{L}+c_{R}\right)$. 集中力 $P$ が左の支持点から距離 $d$ (または右の支持点加距離 $d^{\prime}=L-d$ )の位置に作用 している. 負荷点がはく離部分上にあり（すなわち $\left.d>a_{L}\right)$, しかも $c_{L}<c_{R}$ なる場合を考える.

はく離部分 $\mathrm{BD}$ 間において, 仮想的にはりを点 $\mathrm{B}, \mathrm{D}$ で切り離し, 全体のはりを三つの要素 $\mathrm{AB}, \mathrm{BD}, \mathrm{DF}$ に分離する. はく離部分 $\mathrm{BD}$ 間は両端がヒンジで止め られた重ねばりとみなすことができる(5).二つのヒン

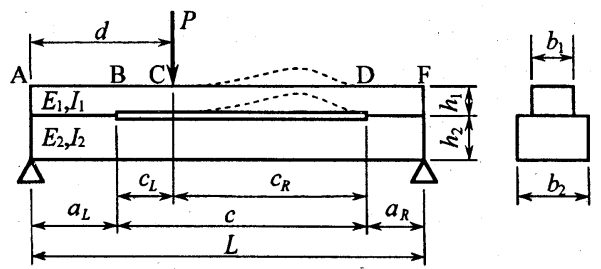

Fig.1 Three-point bending of a laminated beam containing a delamination
ジの作用は，上のはりに対しては，はりの両下すみ部 に未知の水平方向圧縮力， $-Z$ ，及び垂直上向きに作 用する反力 $R_{B} ， R_{D}$ ，下のはりに対しては，はりの両 上すみ部に作用する引張力 $Z$ 及び垂直下向きの反力, $R_{B} ， R_{D}$ に置き換えられる. はく離部分 $\mathrm{BD}$ 間の上下 のはりの自由体線図を図 2 に示寸。

最初に，これら上下のはりのたわみを解析する. 座 標軸は左端 (B 点)を原点にとり， $x$ は右向きを，yは 下向きを正にとる. 負荷点 $\mathrm{C}$ は, $\mathrm{B}$ 点寄りにあるとし て, はく離部分の局所座屈は区間 $\mathrm{CD}$ で起り，区間 $\mathrm{BC}$ においては，はく離面は相互接触しているとする。 こ の相互接触力を $\pm q(x)$ とする. このほか左端（B 点） にモーメント $M_{1 B}, M_{2 B}$, せん断力 $\alpha_{1} F_{B}, \beta_{1} F_{B}$, 右端 (D 点)にモーメント $M_{1 D}, M_{2 D}$ ，せん断力 $\alpha_{3} F_{D}$ ， $\beta_{3} F_{D}$ が作用している. $\alpha_{1}, \beta_{1}, \alpha_{3}, \beta_{3}$ は定数で あり $\alpha_{1}+\beta_{1}=1 ， \alpha_{3}+\beta_{3}=1$ を満足している.

正確には接触区間の長さを最初は未知として取り 扱わなければならないが，解析は非常に面倒になるで あろう. そこで, 前述のように単純化のために, 相互 接触は $\mathrm{BC}$ 間に生じると仮定したわけであるが，この 仮定の導入にあたっては，本来上層のみに作用してい る外力 $P$ を分割し，上層に $\alpha_{2} P$, 下層に $\beta_{2} P$ の力

$\left(\alpha_{2}+\beta_{2}=1\right)$ が作用するものとしなければならない. $\alpha_{2}, \beta_{2}$ は問題を解く過程で決定される. なお，後述 寸る実験值との比較から，この荷重の分割は結果的に 大きな誤差を生じさせないことがわかる.

カとモーメントのつり合いより次式が得られる.

$$
\begin{aligned}
& F_{B}=P d^{\prime} / L, \quad F_{D}=P d / L \\
& M_{1 B}+M_{2 B}=F_{B} a_{L}, M_{1 D}+M_{2 D}=F_{D} a_{R}
\end{aligned}
$$

上下のはりのそれぞれの $x$ 点断面における中立軸回り のモーメントを $M_{\mathrm{x} 1}, M_{x 2}$ ，たわみを $y_{1}, y_{2}$ ，とする.

最初にはく離部分の BC 間について考える．曲げモ ーメントは下向きに凸に曲げるように作用するときを 正と寸ると以下のようになる.

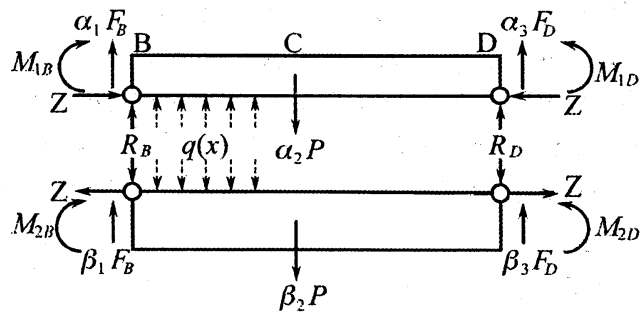

Fig.2 Free-body diagrams for the interval BD 


$$
\begin{aligned}
& M_{x 1}=M_{1}+\alpha_{1}^{\prime} F_{B} x+Z y_{1}+\int_{0}^{x} q\left(x^{\prime}\right)\left(x-x^{\prime}\right) d x^{\prime} \\
& M_{x 2}=M_{2}+\beta_{1}^{\prime} F_{B} x-Z y_{2}-\int_{0}^{x} q\left(x^{\prime}\right)\left(x-x^{\prime}\right) d x^{\prime} .
\end{aligned}
$$
ここで,

$$
\begin{aligned}
& \alpha_{1}^{\prime} F_{B}=\alpha_{1} F_{B}+R_{B}, \quad \beta_{1}^{\prime} F_{B}=\beta_{1} F_{B}-R_{B}, \\
& \left(\alpha_{1}^{\prime}+\beta_{1}^{\prime}=1\right),
\end{aligned}
$$

上下それぞれのたわみの微分方程式は次のようになる.

$$
\frac{d^{2} y_{1}}{d x^{2}}=-\frac{M_{x 1}}{D_{1}}, \frac{d^{2} y_{2}}{d x^{2}}=-\frac{M_{x 2}}{D_{2}}
$$

ここで， $D_{1}, D_{2}$ は上下それぞれのはりの曲け剛性で $D_{i}=E_{i} I_{i}, I_{i}=b_{i} h_{i}{ }^{3} / 12(i=1,2)$. 上下のはりのたわ みは等しい $\left(y_{B C}=y_{1}=y_{2}\right)$ とおき, $x=0$ で $y_{B C}=$ 0 とすると $\mathrm{BC}$ 間のたわみは次式で与えられる.

$$
y_{B C}=s_{1} x^{3}+s_{2} x^{2}+s_{3} x
$$

ここで,

$$
\begin{aligned}
& s_{1}=-F_{B} /(6 D) \\
& s_{2}=\left(-F_{B} a_{L}+\frac{1}{2} h Z\right) /(2 D)
\end{aligned}
$$

$D=D_{1}+D_{2}, h=h_{1}+h_{2}$ であり, $\mathrm{s}_{3}$ は未定定数であ る. 相互接触力は $Z$ の関数として次式で与えられる.

$$
q(x)=-Z \frac{d^{2} y_{B C}}{d x^{2}}=\frac{d^{\prime} P Z}{L D}\left(x+a_{L}-\frac{L h Z}{2 d^{\prime} P}\right)
$$

また式 (5) で与えられる材端モーメント $M_{i} \quad(i=1,2)$ も $Z$ の関数として表され，次式となる.

$$
\begin{gathered}
M_{i}=-\left.D_{i} y_{B C}^{*}\right|_{x=0}=D_{i}\left(F_{B} a_{L}-h Z / 2\right) / D \\
(i=1,2)
\end{gathered}
$$

次に，はく離部分 $\mathrm{CD}$ 間について考える.この区間 では局所座屈が起こり上下のはりは，互いに接してお らず，相互接触力は存在しない．上下のはりのそれぞ れの $x$ 点断面における中立軸回りのモーメント $M_{x 1}$, $M_{x 2}$ は式(10)を用いて計算すると以下のようになる.

$$
\begin{aligned}
M_{x 1}= & M_{1}+\alpha_{1}^{\prime} F_{B} x+f_{1} Z-f_{2} Z x \\
& +Z y_{1}(x)-\alpha_{2} P\left(x-d+a_{L}\right) \\
M_{x 2}= & M_{2}+\beta_{1}^{\prime} F_{B} x-f_{1} Z+f_{2} Z x \\
& -Z y_{2}(x)-\beta_{2} P\left(x-d+a_{L}\right)
\end{aligned}
$$

ここで,

$$
\begin{aligned}
& f_{1}=\frac{-F_{B}\left(d-a_{L}\right)^{2}}{D}\left[\frac{d-a_{L}}{3}+\frac{1}{2}\left(a_{L}-\frac{h Z}{2 F_{B}}\right)\right] \ldots \\
& f_{2}=\frac{F_{B}\left(d-a_{L}\right)}{2 D}\left(-d-a_{L}+\frac{h Z}{F_{B}}\right) \ldots \ldots \ldots \ldots . .
\end{aligned}
$$

式（6）に式 (12)，(13)を代入して解くと, 上下層 それぞれのたわみは以下の式で与えられる.

$$
\begin{gathered}
y_{1}=A_{1} \sin \left(k_{1} x\right)+B_{1} \cos \left(k_{1} x\right)-\left(M_{1}+\alpha_{1}^{\prime} F_{B} x\right) / Z \\
-f_{1}+f_{2} x+\alpha_{2} P\left(x-d+a_{L}\right) / Z
\end{gathered}
$$

$\left.y_{2}=A_{2} \exp \left(k_{2} x\right)+B_{2} \exp \left(-k_{2} x\right)+\left(M_{2}+\beta_{1}^{\prime} F_{B} x\right)\right) / Z$ $-f_{1}+f_{2} x-\beta_{2} P\left(x-d+a_{L}\right) / Z$

ここで,

$$
k_{1}=\sqrt{Z / D_{1}}, \quad k_{2}=\sqrt{Z / D_{2}}
$$

次に, 図 1 の接着部分 $\mathrm{AB}, \mathrm{DF}$ 間のたわみを考える. $\mathrm{AB}, \mathrm{DF}$ 間のたわみをそれぞれ $y_{A B}, y_{D F}$ とし $x$ 座 標の原点を $\mathrm{A}$ 点にとると,たわみは以下のように与え られる.

$$
\begin{aligned}
& y_{A B}=-F_{B} x^{3} /\left(6 D^{\prime}\right)+s_{4} x \\
& y_{D F}=\frac{P d}{6 L D^{\prime}} x^{3}-\frac{P d}{2 D^{\prime}} x^{2}+s_{5} x+s_{6}
\end{aligned}
$$

ここで, $D^{\prime}$ は接着はりの曲け剛性であり次式により 与えられる。

$$
D^{\prime}=D+h^{2} D_{0} / 4
$$

ここで,

$$
D_{0}=1 /\left(\left(b_{1} E_{1} h_{1}\right)^{-1}+\left(b_{2} E_{2} h_{2}\right)^{-1}\right\rfloor
$$

さらに, $\left.y_{D F}\right|_{x=L}=0$ を考慮すると次式が得られる.

$$
s_{6}=\frac{P d L^{2}}{3 D^{\prime}}-s_{5} L
$$

九つの未定定数 $A_{i}, B_{i}(i=1,2), s_{3} \sim s_{5}, \alpha_{1}{ }^{\prime}, \alpha_{2}$, は $\mathrm{B} ， \mathrm{C} ， お よ ひ ゙ \mathrm{D}$ 点におけるたわみとたわみ角の連 続条件から $Z$ の関数として決定される. これらは付録 に示してある.

最後に, 軸力 $Z$ を求める. 上下のはりの中立面の長 さは，変形以前には同一であり，変形後もそれぞれの 中立面は，はりの垂直断面と直交しているという条件 から，以下の方程式を得る. 
$F(Z)=0$

ここで,

$$
\begin{gathered}
F(Z)=\frac{Z c}{E_{1} h_{1} b_{1}}+\frac{Z c}{E_{2} h_{2} b_{2}}+\frac{1}{2} \int_{d-a_{L}}^{c}\left(y_{1}^{\prime}\right)^{2} d x \\
-\frac{1}{2} \int_{d-a_{L}}^{c}\left(y_{2}^{\prime}\right)^{2} d x-\frac{h}{2}\left(\theta_{L}+\theta_{R}\right)
\end{gathered}
$$

上式において， $\theta_{L} ， \theta_{R}$ ，はそれぞれ $\mathrm{B}$ 点，D点に おけるはりの傾きである. すなわち

$$
\theta_{L}=\left.\frac{d y_{B C}}{d x}\right|_{x=0}=s_{3}{ }^{\prime}, \quad \theta_{R}=-\left.\frac{d y_{1}}{d x}\right|_{x=c}
$$

また，式中に現れる積分は簡単に計算できる．式(24) は $Z$ に対する非線形方程式であり, 数值的に解く必要 がある. $Z$ を求めることで全ての未定定数が決まる. そして負荷点におけるたわみは次式から得られる.

$$
\delta=\left.y_{A B}\right|_{x=a_{L}}+\left.y_{B C}\right|_{x=c_{L}}
$$

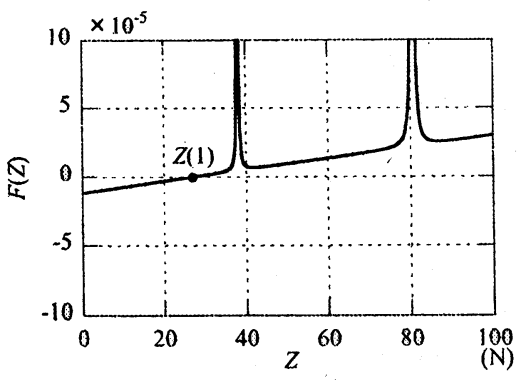

(a) $P=1.0(\mathrm{~N})$

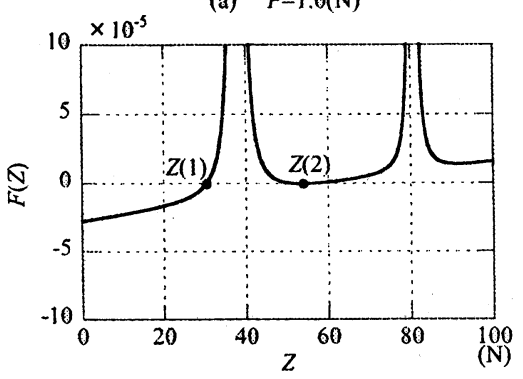

(b) $\quad P=2.3(\mathrm{~N})$

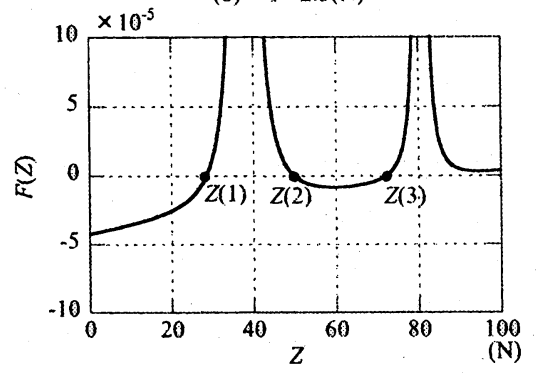

(c) $P=3.5(\mathrm{~N})$

Fig.3 Plots of $F(Z)$ for several values of the applied force
2-2 軸力 Zの数值解 ここでモデルはりとして, 上層が厚さ $h_{1}=0.5 \mathrm{~mm}$, 幅 $b_{1}=20 \mathrm{~mm}$ のステンレス鋼は り, 下層が厚さ $h_{2}=2 \mathrm{~mm}$, 幅 $b_{2}=30 \mathrm{~mm}$ のアルミニウ ムはりである積層はり（支点間距離は $L=400 \mathrm{~mm}$ ）を 例にとって計算する. ヤング率はそれぞれ $E_{1}=195.2$ $\mathrm{GPa}, E_{2}=72.4 \mathrm{GPa}$ とする（これらの值は現著者らの 実測值である)。はく離長さを $c=240 \mathrm{~mm}$, また $a_{R}$ $=50 \mathrm{~mm}, d=150 \mathrm{~mm}$ とし, 荷重 $P$ を変化させる.

ここで, 解くべき方程式 $F(Z)=0$ の解の挙動を調心 るために $F(Z)$ を $Z$ に対してプロットする. 図 3(a)

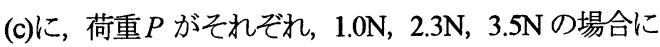
対する $F(Z)$ のグラフを示す. 荷重が小さい場合, 解 は一つだけ存在し, 荷重が増加するにつれて解の個数 も二個（図 3(b)），三個（図3(c)）と増加する. 図 3 (a)-(c)の解 Z(1)，Z(2)，Z(3)に対応するたわみ曲線を描 いてみたところ，Z(1)に対しては CD 間の上下のはり の位置関係が逆転し，また Z(3)に対しては CD 間の一 部で上のはりが下のはりの下側に来るたわみ曲線とな り，したがって解Z(1) とZ(3) は不適当であることが わかった. 一方，Z(2)に対するたわみ曲線は矛盾を含 まない. すなわち, Z(2) が我々の求める座屈後の軸力 となる. また, この二番目の解が初めて現れる時の荷 重が臨界座屈荷重となる. 今の場合, 図 $3($ b) より臨界 座屈荷重は $P \approx 2.3 \mathrm{~N}$ である.

臨界座屈荷重より小さい荷重に対しては, 座屈解は 存在しないから, はく離面の相互接触を仮定しなけれ ばならない. この場合の解析はすでになされている. 負荷点におけるたわみ $\delta$ は荷重 $P$ に比例し，はりのコ ンプライアンス $\Phi(=\delta / P)$ は次式で与えられる(5).

$$
\begin{gathered}
\Phi=-\frac{1}{3 L^{2}}\left(\frac{1}{D}-\frac{1}{D^{\prime}}\right)\left[d^{2}\left(d^{\prime}-c_{R}\right)^{3}+d^{\prime 2}\left(d-c_{L}\right)^{3}\right] \\
-\frac{1}{4 c}\left(\frac{1}{D}-\frac{1}{D^{\prime}}\right) f^{2}+\frac{d^{2} d^{\prime 2}}{3 L D}
\end{gathered}
$$

ここで,

$$
f=\left[\left(2 a_{L}+c_{L}\right) c_{L} d^{\prime}+\left(c_{R}+2 a_{R}\right) c_{R} d\right] / L
$$

図 4 に $P$ と $\delta$ の関係を示寸. $P-\delta$ 関係はほぼバイ リニアであり, 座屈後にはりがたわみやすくなること がわかる. またこの図では実験值もプロットしてある が, 実験の詳細については 4 章で述べる.

\section{$2 \cdot 3$ 集中力が接着部分上に作用する場合の局所座} 屈座屈によるはく離進展の一般的挙動を調べるた めには，負荷点 $\mathrm{C}$ が $\mathrm{AB}$ 間にある場合 $\left(d<a_{L}\right)$ も扱 う必要があるが, この場合の解析はすでになされてい 
る 単であった. 問題は式 (24)，(25) と類似の非線形方 程式を解くことに帰せられるが，この非線形方程式の 解の挙動は, 前節と同様であり, 二番目に小さい解 $Z$ (2)が座屈後に対応する唯一の解となり, 臨界座屈荷 重 $P_{\mathrm{cr}}$ は二番目に小さい解が初めて現れるときの荷重 となる．前節のモデルはりを対象に，また同様に $a_{R}=50 \mathrm{~mm}, d=150 \mathrm{~mm}$ として, はく離長さを $100 \mathrm{~mm}$ から $280 \mathrm{~mm}$ と変化させて, $P_{\mathrm{a}}$ を計算した. 結果を図 5 に示寸. $c / L>0.5$ の領域は負荷点がはく離部内に ある場合であるが，この領域において，座屈する区間 CD は一定であるが，はく離長さの増大と共に座屈荷 重はわずかではあるが減少している.

一方, 荷重が臨界座屈荷重 $P_{c r}$ より小さいとき, は く離面は相互接触をし, 負荷点のたわみ $\delta$ は荷重 $P$ に 比例する.は離部外部に荷重が作用する場合, コン プライアンスは次式で与えられている(5).

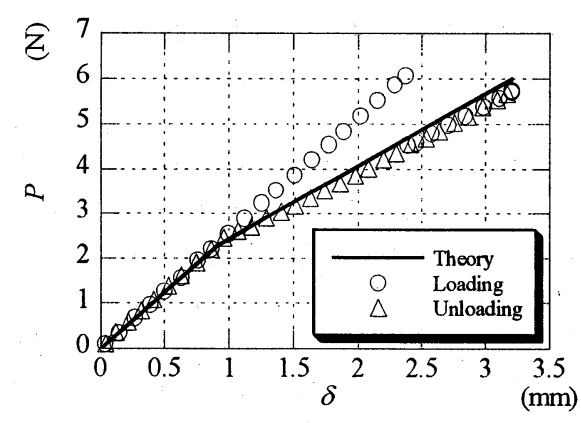

Fig.4 Relation between the applied load $P$ and the deflection at the point of load application $\delta$ for $\mathrm{c}=240 \mathrm{~mm}\left(d>a_{\mathrm{L}}\right)$

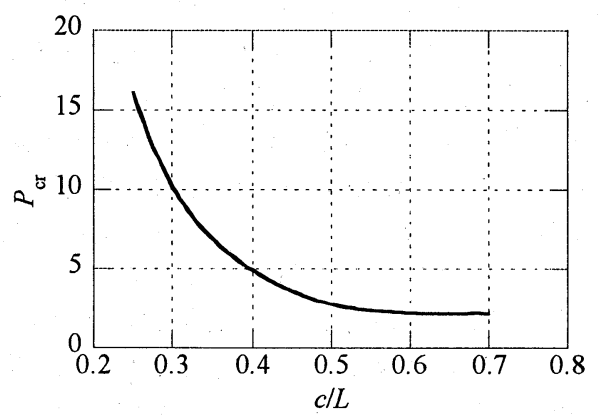

Fig.5 Critical buckling load $P_{c r}$ plotted for crack length $c / L \quad\left(a_{R}=50 \mathrm{~mm}, d=150 \mathrm{~mm}\right)$

$$
\Phi=\frac{d^{2} c^{3}}{12 L^{2}}\left(\frac{1}{D}-\frac{1}{D^{\prime}}\right)+\frac{d^{2} d^{\prime 2}}{3 D^{\prime} L}
$$

すでに文献 (7) で示されたように, 負荷点がはく離 部外にある場合でも， $P-\delta$ 関係はほぼバイリニアと なる. 前出のモデルはりに対し座屈前後の $P-\delta$ 直線 のコンプライアンス（座屈後に対しては傾きの逆数） を負荷点がはく離内および外にある場合について計算 し，実験（詳細については 4 章参照）と比較した結果 を図6に示す．負荷点がはく離部外にある場合，はく 離長さが短いことを反映し，座屈前後のコンプライア ンスの差は図4に比べて小さくなっている.

\section{3. エネルギー解放率}

この章では上下層のはりの幅が等しい $\left(b_{1}=b_{2}=b\right)$ として，座屈がエネルギ一解放率に対して与える影響を調 ベる. よく知られているように，負荷点におけるたわ奴 荷重が比例するとき，エネルギ一解放率 $G$ は，荷重一定条 件の下のクラック進展に対して

$$
G=\left(P^{2} / 2 b\right) d \Phi / d c
$$

で与えられる (コンプライアンス法).この式を適用す ると, 負荷点がはく離部分上にあり, かつはく離表面 が相互接触しながら進展する場合，はく離左端，右端 のそれぞれのエネルギー解放率 $G_{a L}, G_{a R}$ は式(28)よ り以下のように得られる(5).

$$
\begin{aligned}
G_{a L} & =\frac{P^{2}}{2 b} \frac{d \Phi}{d c_{L}}=\frac{P^{2} c^{2}}{8 b}\left(\frac{1}{D}-\frac{1}{D^{\prime}}\right)\left[\frac{d^{\prime}}{L}-\left(\frac{c_{R}}{c}\right)^{2}\right]^{2} \\
G_{a R} & =\frac{P^{2} c^{2}}{8 b}\left(\frac{1}{D}-\frac{1}{D^{\prime}}\right)\left[\frac{d}{L}-\left(\frac{c_{L}}{c}\right)^{2}\right]^{2}
\end{aligned}
$$

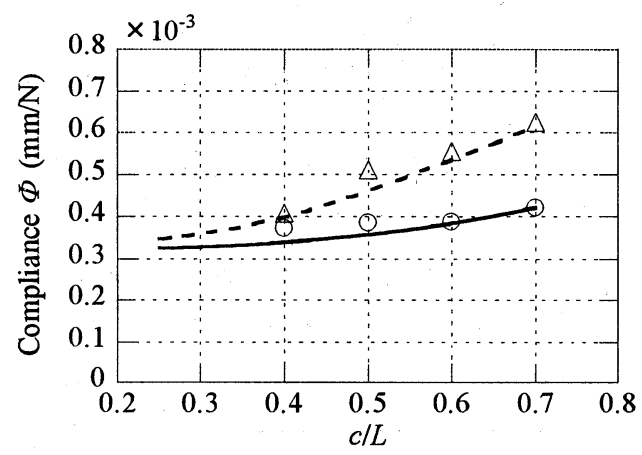

Fig.6 Comparison of the compliances between theory and experiments $\left(a_{R}=50 \mathrm{~mm}\right.$, $d=150 \mathrm{~mm}$ ) 
負荷点が接着部分上にある場合, クラック両端に対し 式(30)から次式を得る.

$$
G_{a L}=G_{a R}=\frac{P^{2} d^{2} c^{2}}{8 b L^{2}}\left(\frac{1}{D}-\frac{1}{D^{\prime}}\right)
$$

座屈後の状態におけるエネルギー解放率の計算には, コンプライアンス法は使えない, そこで, Suo と Hutchinson $^{(8)}$ の結果を用いる. 彼らは図 7に示されるような モーメントと軸力による負荷を受ける単位幅の積層は り中の界面クラックに対し，エネルギー解放率の公式 を導いた. 平面応力条件を仮定し，彼らの結果を本論 文の座屈モデルに適用すると, エネルギー解放率は次 式で与えられる.

$$
G=\frac{1}{2 E_{1}}\left[\frac{P_{0}^{2}}{A h_{1}}+\frac{M_{0}^{2}}{B h_{1}^{3}}+\frac{2 P_{0} M_{0}}{\sqrt{A B} h_{1}^{2}} \sqrt{\frac{\left(D^{\prime}-D\right) D_{1}}{\left(D^{\prime}-D_{1}\right) D}}\right]
$$

ここで

$$
\begin{aligned}
& M_{0}=\left(M_{1}^{*}-D_{1} M_{3} / D^{\prime}\right) / b \\
& P_{0}=\left[Z-h D_{0} M_{3} /\left(2 D^{\prime}\right)\right] / b
\end{aligned}
$$

$M_{1} *$ と $M_{3}$ はクラック左端または右端それぞれに 対応するモーメントであり，図７に示す向きに作用す るときを正とする. 定数 $A$ と $B$ は次式で与えられる.

$$
A=\frac{D_{0} D_{2}}{b E_{1} h_{1}\left(D^{\prime}-D_{1}\right)}, \quad B=\frac{D_{2}}{12 D}
$$

負荷点がはく離部分上にある場合，はく離左端に対 して式（11）より次式が得られる.

$$
M_{1}^{*}=D_{1}\left(F_{B} a_{L}-h Z / 2\right) / D, \quad M_{3}=F_{B} a_{L}
$$

同様にはく離右端に対しては, $M_{1}$ *は式(12)の $x$ に $c$ を代入することで得られ，また $M_{3}=F_{D} a_{R}$ となる. 接着部分上に荷重が作用する場合も同様にして $M_{1} *$, $M_{3}$ が得られる.

例として，前章で用いたはり $(L=400 \mathrm{~mm}, d=$ $\left.150 \mathrm{~mm}, a_{R}=50 \mathrm{~mm}\right)$ について数值計算を行った. た

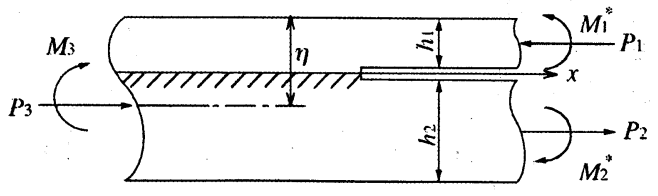

Fig.7 Split-beam element under general loading condition ( $\eta$ is the distance of the neutral axis of the bonded beam from the top surface)

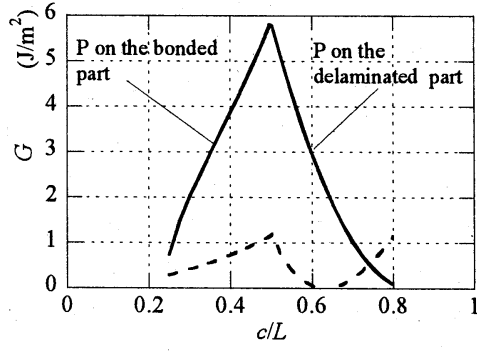

(a)Left side

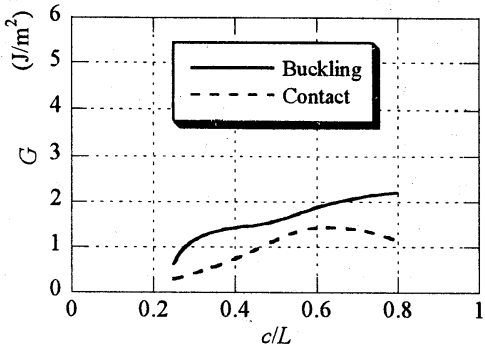

(b)Right side

Fig.8 Energy release rates $\left(P=11 \mathrm{~N} a_{R}=50 \mathrm{~mm}\right.$, $d=150 \mathrm{~mm}, b_{I}=b_{2}=30 \mathrm{~mm}, h_{1}=0.4 \mathrm{~mm}$ )

だし，二つのはりの幅は同じ $\left(b_{1}=b_{2}=30 \mathrm{~mm}\right)$ とし，上 層の厚さを $0.4 \mathrm{~mm}$ としている. はく離長さは $100 \mathrm{~mm}$ ～320mm に変化させている. 荷重 $P$ としては $c=$ $100 \mathrm{~mm}$ のはく離の臨界座屈荷重である $11 \mathrm{~N}$ 用いた.

はく離左端および右端の座屈前後のエネルギ一解放 率とはく離長さ $(c / L)$ の関係を図 $8(a)$, (b)に示す. 左端での $c / L>0.74$ なる範囲を除いては, 座屈によっ てエネルギ一解放率が増大寸ることがわかる．またこ の効果ははく離左端,すなわち負荷点に近いはく離端, において顕著である.

また図 8(a)に着目すると，座屈モデルと接触モデル の両者ともはく離長さ $c / L$ が 0.25 から 0.5 まで増大す るのに伴い，言い換えるとはく離左端の位置が負荷点 と一致するまでは, エネルギ一解放率は増大している. さらにはく離長さが増加するとエネルギ一解放率は减 少に転じる.この現象は外荷重によりはく離先端付近 ではく離面が閉じられることによるものと考えられる。

図 8(a)，(b)を比較してわかるように，初期はく離長 さ $c / L$ が 0.65 より短い場合は, はく離左端のエネル ギ一解放率は右端のそれより大きい. したがって, 界 面の破壊じん性值が比較的大きく，はく離進展が座屈 によって起こる場合は，例えば初期はく離 $c=120 \mathrm{~mm}$ に対して，はく離右端は停留したまま，左端だけが座 屈により負荷点方向一進展すると考えられる. 破壊じ ん性が大きな界面においては，一般にはく離倠展は座 
屈が生じた後に生じると予想される.したがって，は く離進展の評価は座屈を考慮した上で行うべきである.

\section{4. 実 験}

ここで 2.2 節で用いたモデルと同じステンレス鋼と アルミニウムで作られた積層はりを使用して実験を行 った. 厚さ $0.08 \mathrm{~mm}$ の薄い PTFE テープをステンレス はりのはく離先端となるべき箇所に貼り，はく離端が はりの軸に垂直かつ直線状になるようにした. また直 径 $0.04 \mathrm{~mm}$ のステンレスワイヤーを二本, $8 \mathrm{~mm}$ の間隔 で,アルミニウムの接着面側に全長にわたって張った. この作業は, 薄いステンレス層のはく離部分において 自重による初期たわみが生じないようにするためであ る.はく離部を除いて二枚のはりをエポキシ系接着剤 (アラルダイト) で接着した. はく離長さがそれぞれ $c=160,200,240,280 \mathrm{~mm}$ の 4 種類の積層材料を作製 した. 全てのはりのはく離右端の位置は，はり右端か ら $50 \mathrm{~mm}\left(=a_{R}\right)$ としている. これらの試験片に対し て万能試験機を用いて三点曲げ試験を行った. 負荷点 は, はりの左端から $150 \mathrm{~mm}(=d)$ である. 負荷点変 位はレーザー変位計により測定した。

はく離長さ $c=240 \mathrm{~mm}$ に対する荷重 $P$ と負荷点たわ み $\delta$ の関係の実験結果は前出の図 4 に示した. このグ ラフからわかるように実験の負荷時において得られた 臨界座屈荷重は理論値のそれより二倍程大きい:この 傾向は他の試験片に対しても同様であった. 座屈後は 直ちに荷重は减少し, 理論で得られた $P-\delta$ 関係に近 い值になる. 一方, 除荷時においては臨界座屈荷重も 含め, 荷重とたわみの関係は理論と実験が非常によく 一致していることがわかる.

全ての実験において, 図4のように $P-\delta$ 関係はほ ぼバイリニアであった. はく離部分が接触している状 態と座屈を起こしている状態に対するコンプライアン ス $\Phi$ とはく離長さ $c / L$ の関係についての理論と実験 の比較は図6に示してある.この図から荷重一たわみ 関係の傾きは実験值と理論值でよく一致していること がわかる.

なお，負荷点直下でのみはく離面が接触し，図 1 の $\mathrm{BC}$ おび $\mathrm{CD}$ 間の両部分で座屈が起こるという現象 は, 実験においては観察されなかった. したがって左 右対称な場合を除けば今回のモデルは十分な一般性を 有していることが確認された.

\section{5. 結 言}

非対称三点曲げを受ける内部界面はく離を有する積 層はりの解析を行った. 負荷点がはく離部分上にある
場合，荷重が臨界值に達すると，負荷点と負荷点から より離れたはく離端の間で, はく離部分上層部が局所 座屈を起こす。一方, 負荷点と負荷点に近い方のはく 離端の間では上下のはく離面は相互接触を保つ. 軸力 に対する非線型方程式を導き，解の挙動を調べた。 そ の結果, 臨界座屈荷重は二番目の解が初めて現れると きの荷重であることがわかった. これより小さい荷重 下では Toya ら ${ }^{(5)}$ のはく離面が全面接触していると仮 定した解析が有効である. 荷重と負荷点におけるたわ みの関係は, 実験で得られた関係と良く一致している. ただし，負荷時における臨界座屈荷重は，理論と実験 值では二倍程度の違いが見られた.この違いの原因の 解明は将来の課題として残っている.

エネルギ一解放率に対する座屈の影響についても解 析を行った. エネルギ一解放率ははく離面が全面接触 している場合と比較して一般に座屈により増大寸る. このことは積層はりの界面強度の評価は座屈を考慮し て行わなければならないことを意味している.

最後に, 本研究は文部科学省科学研究費補助金 [ 基 盤研究 (C) 17560073] の援助を受けて実施されたこ とを付記し，謝意を表する.

\section{付 録}

B, C，D点でのたわみとたわみ角の連続条件から以 下の式を得る. B 点で

$$
\left.\frac{d y_{A B}}{d x}\right|_{x=a_{L}}=\left.\frac{d y_{B C}}{d x}\right|_{x=0}
$$

$\mathrm{C}$ 点で,

$$
\begin{gathered}
\left.y_{B C}\right|_{x=d-a_{L}}=\left.y_{1}\right|_{x=d-a_{L}}=\left.y_{2}\right|_{x=d-a_{L}} \\
\left.\frac{d y_{B C}}{d x}\right|_{x=d-a_{L}}=\left.\frac{d y_{1}}{d x}\right|_{x=d-a_{L}}=\left.\frac{d y_{2}}{d x}\right|_{x=d-a_{L}}
\end{gathered}
$$

$\mathrm{D}$ 点で,

$$
\left.y_{1}\right|_{x=c}=\left.y_{2}\right|_{x=c},\left.\quad y_{A B}\right|_{x=a_{L}}+\left.y_{1}\right|_{x=c}=\left.y_{D F}\right|_{x=a_{L}+c}
$$

$$
\left.\frac{d y_{1}}{d x}\right|_{x=c}=\left.\frac{d y_{2}}{d x}\right|_{x=c}=\left.\frac{d y_{D F}}{d x}\right|_{x=a_{L}+c}
$$

式 $\left(41_{2}\right) ，\left(42_{2}\right) ，\left(43_{1}\right) ， お よ ひ ゙\left(44_{1}\right)$ は $A_{i}, B_{i}$ $(i=1,2)$ のを末知数として含んでいる. そこで, $\left(41_{2}\right)$ と $\left(42_{2}\right)$ を解いて $A_{1}$ と $B_{1}$ を $A_{2}$ と $B_{2}$ で表す. 次に $\left(43_{1}\right)$ と $\left(44_{1}\right)$ に代入して解くと $A_{2}$ と $B_{2}$ が 得られる. このようにして,

$$
A_{2}=\left(\delta_{1} a_{22}-\delta_{2} a_{12}\right) \Delta \Delta, B_{2}=\left(-\delta_{1} a_{21}+\delta_{2} a_{11}\right) \Delta \Delta
$$




$$
\begin{aligned}
& A_{1}=a_{1} \sin \theta+a_{2} \cos \theta-a_{3} \cos \theta \\
& B_{1}=a_{1} \cos \theta-a_{2} \sin \theta+a_{3} \sin \theta
\end{aligned}
$$

ここで,

$$
\begin{aligned}
\theta= & k_{1}\left(d-a_{L}\right) \\
a_{1}= & A_{2} \Gamma+B_{2} / \Gamma+\left[M-F_{B}\left(d-a_{L}\right)\right] / Z \\
a_{2}= & \left(k_{2} / k_{1}\right) A_{2} \Gamma-B_{2} / \Gamma \\
a_{3}= & \left(P-F_{B}\right) / k_{1} Z \ldots \ldots \ldots \ldots \ldots \ldots \ldots \ldots \ldots \ldots \ldots \ldots \ldots \ldots \ldots \ldots \ldots \ldots \ldots \ldots \ldots \ldots \ldots \ldots \ldots \ldots \ldots \ldots \\
a_{11}= & {\left[\cos k_{1} \bar{e}+\left(k_{2} / k_{1}\right) \sin k_{1} \bar{e}\right] \Gamma } \\
& \quad-\exp \left(k_{2} c\right)
\end{aligned}
$$

$$
\begin{aligned}
a_{12}= & {\left[\cos k_{1} \bar{e}-\left(k_{2} / k_{1}\right) \sin k_{1} \bar{e}\right] / \Gamma } \\
& -\exp \left(-k_{2} c\right)
\end{aligned}
$$

$$
\begin{gathered}
a_{21}=\left[\sin k_{1} \bar{e}-\left(k_{2} / k_{1}\right) \cos k_{1} \bar{e}\right] \Gamma \\
+\left(k_{2} / k_{1}\right) \exp \left(k_{2} c\right)
\end{gathered}
$$

$$
\begin{gathered}
a_{22}=\left[\sin k_{1} \bar{e}+\left(k_{2} / k_{1}\right) \cos k_{1} \bar{e}\right] / \Gamma \\
-\left(k_{2} / k_{1}\right) \exp \left(-k_{2} c\right)
\end{gathered}
$$

$$
\begin{aligned}
\delta_{1}= & {\left[M+c F_{B}-\bar{e} P+\left(P-F_{B}\right)\left(\sin k_{1} \bar{e}\right) / k_{1}\right.} \\
& \left.-\left\{M+F_{B}\left(d-a_{L}\right)\right\} \cos k_{1} \bar{e}\right] / Z
\end{aligned}
$$

$$
\begin{aligned}
\delta_{2}=- & {\left[\left\{M+F_{B}\left(d-a_{L}\right)\right\} / \dot{Z}\right] \sin k_{1} \bar{e} } \\
& +\left[\left(P-F_{B}\right) /\left(k_{1} Z\right)\right]\left(1-\cos k_{1} \bar{e}\right)
\end{aligned}
$$

$\Delta=a_{11} a_{22}-a_{12} a_{21}$

ここで,

$$
\begin{aligned}
& \Gamma=\exp \left[k_{2}\left(d-a_{L}\right)\right], \bar{e}=a_{L}+c-d, \\
& M=M_{1}+M_{2}=F_{B} a_{L}-Z h / 2
\end{aligned}
$$

他の未知定数は，残りの方程式からすぐに得られ る. このようにして, $s_{3} \sim s_{5}, \alpha_{1}^{\prime}, \alpha_{2}$ は $Z$ の関数 として以下のように得られる.

$$
\begin{aligned}
& s_{3}=J_{1}-\alpha_{1}^{\prime} F_{B} / Z \\
& s_{4}=s_{3}+F_{B} a_{L}^{2} /\left(2 D^{\prime}\right) \\
& +\left(-\alpha_{1}^{\prime} F_{B}+\alpha_{2} P\right) / Z-\left[P d\left(a_{L}+c\right)^{2}\right] /\left(2 L D^{\prime}\right) \\
& +P d\left(a_{L}+c\right) / D^{\prime}
\end{aligned}
$$

$$
\begin{aligned}
\alpha_{2}= & \frac{Z}{P}\left[J_{1}+3 s_{1}\left(d-a_{L}\right)^{2}+2 s_{2}\left(d-a_{L}\right)-f_{2}\right. \\
& \left.-k_{1}\left(A_{1} \cos \theta-B_{1} \sin \theta\right)\right]
\end{aligned}
$$
ここで,

$$
\begin{aligned}
J_{1}= & {\left[A_{1} \sin \theta+B_{1} \cos \theta-M_{1} / Z-f_{1}\right] /\left(d-a_{L}\right) } \\
& +f_{2}-s_{1}\left(d-a_{L}\right)^{2}-s_{2}\left(d-a_{L}\right)
\end{aligned}
$$

$$
\begin{aligned}
J_{2} & =\frac{P d\left(a_{L}+c\right)^{3}}{6 L D^{\prime}}-\frac{P d\left(a_{L}+c\right)^{2}}{2 D^{\prime}}+ \\
+ & {\left[k_{1}\left(A_{1} \cos \left(k_{1} c\right)-B_{1} \sin \left(k_{1} c\right)\right)+f_{2}+\alpha_{2} P / Z\right.} \\
& \left.-P d\left(a_{L}+c\right)^{2} /\left(2 L D^{\prime}\right)+P d\left(a_{L}+c\right) / D^{\prime}\right] \\
& \times\left(a_{L}+c-L\right)+\frac{P d L^{2}}{3 D^{\prime}}+\frac{F_{B} a_{L}^{3}}{6 D^{\prime}}-\left(J_{1}+\frac{F_{B} a_{L}^{2}}{2 D^{\prime}}\right) a_{L} \\
& -A_{1} \sin \left(k_{1} c\right)-B_{1} \cos \left(k_{1} c\right)+\left(M_{1}-\alpha_{2}^{\prime} P \bar{e}\right) / Z \\
& +f_{1}-f_{2} c
\end{aligned}
$$

\section{文 献}

(1) Maikuma, H. et al., Analysis and Experimental Chara-cterization of the Center Notch Flexural Test Specimen for Mode II Interlaminar Fracture, Journal of Composite Materials, Vol.23, No. (1989), pp.756-786.

(2) Suemasu, H. and Majima, O., Multiple Delaminations and Their Severity in Circular Axisymmetric Plates Subjected to Transverse Loading, Journal of Composite Materials, Vol. 30, No. 4 (1996), pp.441-453.

(3) Suemasu, H. and Majima, O., Multiple Delaminations and Their Severity in Nonlinear Circular Plates Subjected to Concentrated Loading, Journal of Composite Materials, Vol. 32, No. 2 (1998), pp. 123-140.

(4) Hutchinson, J. W. and Lu, T. J., Laminate Delamination Due to Thermal Gradients, Transactions of the ASME, Journal of Engineering Materials and Technology, Vol. 117, October (1995), pp.386-390.

(5) Toya. M., et al., Energy Release Rates for an Interface Crack Embedded in a Laminated Beam Subjected to Three-Point Bending, Transactions of the ASME, Journal of Applied Mechanics, Vol. 64, June (1997), pp. 375-382.

(6) Arai, M, et al., Observation of Delamination Process and Its Evaluation in Coating Materials under Compressive Stress, Transactions of the Japan Society of Mechanical Engineers, Series A, Vol. 66, No.641 (2000), pp. 144-150.

(7) Toya, M, et al., Local Delamination Buckling of a Laminated Beam Caused by Bending, Transactions of the Japan Society of Mechanical Engineers, Series A, Vol. 62, No.602 (1996), pp.2242-2249.

(8) Suo, Z. and Hutchinson, J. W., Interface Crack Between Two Elastic Layers, International Journal of Fracture, Vol. 43, No.1 (1990), pp.1-18. 